\title{
Correction to: Where is the gray side of green growth? Theoretical insights, policy directions, and evidence from a multidimensional approach
}

\author{
Mehmet Demiral $^{1}$ (D) Ozge Demiral ${ }^{2}$ \\ Published online: 19 March 2021 \\ (C) Springer-Verlag GmbH Germany, part of Springer Nature 2021
}

\section{Correction to: Environmental Science and Pollution Research https://doi.org/10.1007/s11356-021-13127-x}

The correct image of Figs. 1 and 2 is presented in this paper. The original article has been corrected.

Publisher's note Springer Nature remains neutral with regard to jurisdictional claims in published maps and institutional affiliations.

The online version of the original article can be found at https://doi.org/ 10.1007/s11356-021-13127-x

Mehmet Demiral

mdemiral@ohu.edu.tr

1 Department of Economics, Niğde Ömer Halisdemir University, 51240 Niğde, Turkey

2 Department of International Trade and Logistics, Niğde Ömer Halisdemir University, 51240 Niğde, Turkey 
Fig. 1 Production-based $\mathrm{CO}_{2}$ productivity in the sampled country groups (Country averages, 1996-2018).

Source: OECD (2020)

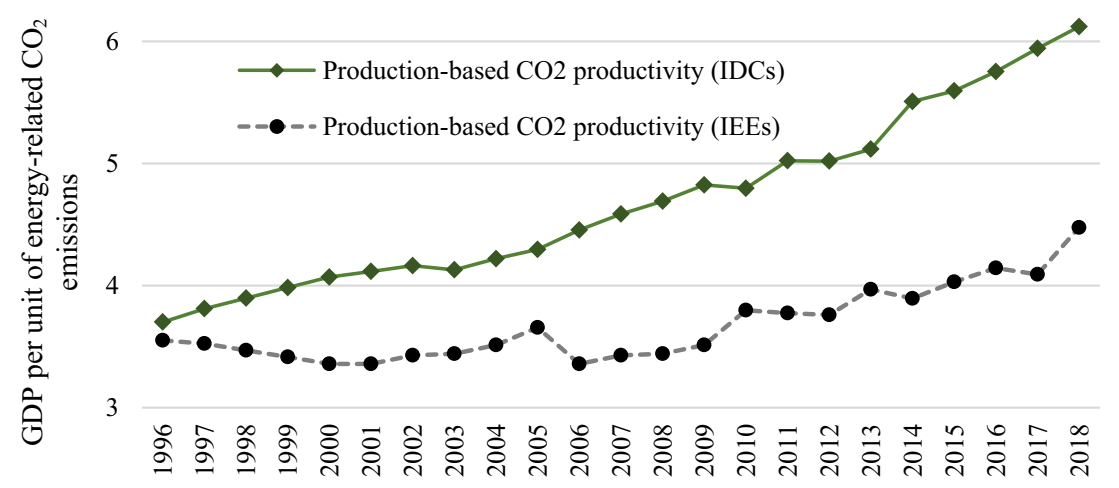

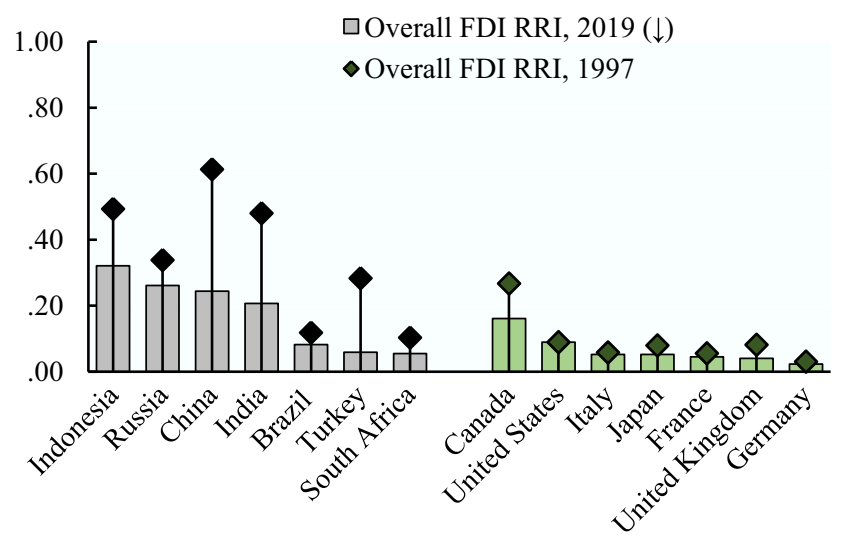

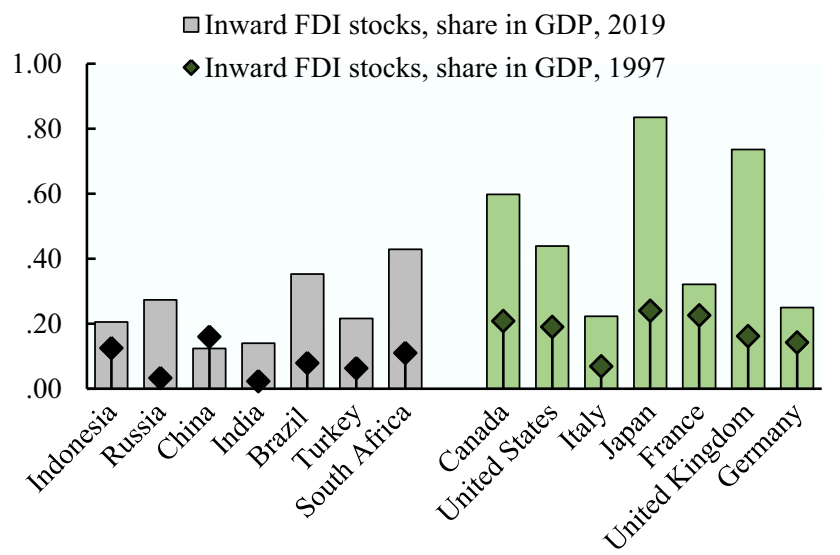

$\square$ Outward FDI stocks, share in GDP, 2019

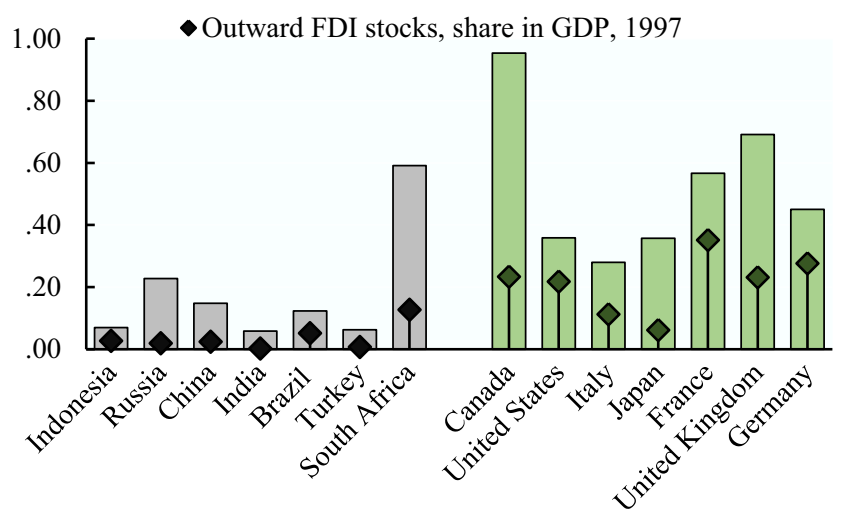

Fig. 2 FDI regulatory restrictiveness indices and FDI stocks (1997, 2019). Source: OECD (2020) and UNCTAD (2020) 